\title{
Effect of Turbidity to the Clogging of the Subsurface Drain
}

\author{
Sunisa Smittakorn, Sasiphorn Sasinawaworakul, and Phattara Chutsikarinton
}

\begin{abstract}
Normally, the subsurface drain is benefit in agricultural area to lower the water table resulting in the increase of the plant productivity. To drain water in some particular areas such as a golf course or rather flat area, the subsurface drain can also be applied. A minor change in the subsurface drain which permeable material in the envelope be replaced by an adsorbent was suggested. This new type of subsurface drain will be served as a sustainable practice to simultaneously discharge surface runoff, reduce the runoff to the drainage system, remove any contaminant from the surface runoff and finally replenish the groundwater. However, clogging is highly possible to occur due to the size of the adsorbent. In this work, the effect of the turbidity to the hydraulic conductivity of two adsorbents; granular activated carbon and a composite material of sand and anthracite was investigated. The source of input water was from a drainage canal in order to have similar turbidity of the surface runoff. Results showed that steady state hydraulic conductivities of both adsorbents were still within the range of typical permeable materials in envelope in this case was gravel. However, it was recommended that granular activated carbon should be selected as a substitute because its steady state hydraulic conductivity was higher than that of a composite material of sand/anthracite and for the practicality during the construction.
\end{abstract}

Index Terms-Shallow aquifer recharge (SAR), subsurface drain, clogging.

\section{INTRODUCTION}

In 2011, one of the worst flood in 50 years occurred in Thailand has resulted in about 40,000 million US dollars (1.4 million million Thai Baht) according to the World Bank [1], not to mention the cost of recovery and reconstruction. Damages and losses were in all of the sectors such as transportation, telecommunication, electricity, water supply and sanitation. In production sector were also hard hit by the flood such as agriculture, manufacturing, tourism, finance and banking. The social and environmental damage were affected by this great flood as well. However, after such the worst flood of Thailand, somehow Thailand has yet faced another water disaster. News of drought has threatened the agricultural sector once again.

With flood and drought alternately occur in Thailand and also many part of the world, such disasters could unfortunately setback an economic growth of a nation. There are many attempts trying to solve both flood and drought simultaneously. Building a reservoir is a simple way to solve such problems by storing the water during the flood and can be later used during the drought. However, a huge dam

Manuscript received August 8, 2016; revised December 17, 2016.

The authors are with Department of Civil Engineering, Thammasat University, Thailand (e-mail: ssunisa@engr.tu.ac.th, sasiphorn_sasi@hotmail.com, Firer_pat@hotmail.com). project has long been criticized for environmental and social impacts [2]. Several measures have been studied to ease the flood and drought. One method which has been studied and applied in many areas is called aquifer storage and recovery.

Aquifer storage and recovery (ASR) is a process in which water such as surface runoff or treated waste water is stored into the ground and can be pumped for later use. There are several ways to store water back into the aquifer such as infiltration basins [3] and recharge wells [4]. An area is required for infiltration basins; therefore alternative plans to restore the aquifer might be applied when land is limited.

It would be convenient if a recharge system can be incorporated as soon as the surplus water is occurred. There are several attempts to reclaim rainwater before it drains to the river. Rain harvesting has gained more attention recently as yet another technique to preserve water [5], [6]. Porous concrete/pavement [7] is also introduced as a sustainable practice because it can reduce the runoff to the drainage system and can increase the recharge to the groundwater as well. One drawback though for the porous concrete is the lack of structural strength so the careful design, mix and construction have to be carried out in order to achieve the strength needed [8].

In previous paper by the authors [9], the subsurface drain with a slight modification was proposed as a mean to mitigate the flood as well as to recharge the groundwater. The distinction between the typical subsurface drain and the proposed one is that an adsorbent will be substituted for the gravel in the envelope material. Since there were evidences that some pollutant from the road runoff can flow farther down to the side of the road [10], [11], it is very crucial to remediate any contaminants before such water being recharged into the aquifer. Hence the adsorbent being replaced in the envelope would serve a purpose.

There were various kinds of adsorbents being studied such as colloidal activated carbon to remove organic compounds [12] or thermally treated Gastropod shell to remediate fluoride [13]. However, such novelty materials might be unsuitable for this case due to the practicality of the preparation and the installation of the envelope material.

Adsorbent considered in previous work was granular activated carbon which is widely accepted as affordable material to remove contaminants. Sand and anthracite combination is another adsorbent used in industrial water treatment process. Normally, the average size of adsorbent is smaller than that of gravel. Therefore, the problem with clogging is pivotal to the longevity of the subsurface drain. In this paper, the effect of turbidity of the surface runoff to hydraulic conductivities of activated carbon and sand/anthracite were investigated. The hydraulic conductivity of adsorbent should be within the range of that of gravel to ensure the permeable characteristics of the 
envelope.

\section{MATERIALS AND Methods}

Hydraulic conductivity of adsorbent was evaluated using a constant head permeability test unit. The test unit consisted of two PVC pipes with the diameter of $10.5 \mathrm{~cm}$. One pipe was filled with granular activated carbon with the depth of $30 \mathrm{~cm}$, while the other was packed with the combination of sand/anthracite to the same length of the activated carbon column. The depth ratio of sand/anthracite was 1:1. Diameter of sand, anthracite and granular activated carbon were $0.1 \mathrm{~cm}$, $0.05 \mathrm{~cm}$ and $0.5 \mathrm{~cm}$, respectively. The constant head in the test unit was fixed at $113 \mathrm{~cm}$. The schematic diagram of the permeability test unit is shown in Fig. 1. Before the effect of turbidity to the hydraulic conductivity of the adsorbent was tested, the typical hydraulic conductivities of granular activated carbon and sand/anthracite had to be verified as a base line by supplying the test unit with tap water. Water passing through the porous media was collected respected to time. Hydraulic conductivities of both media can then be calculated.

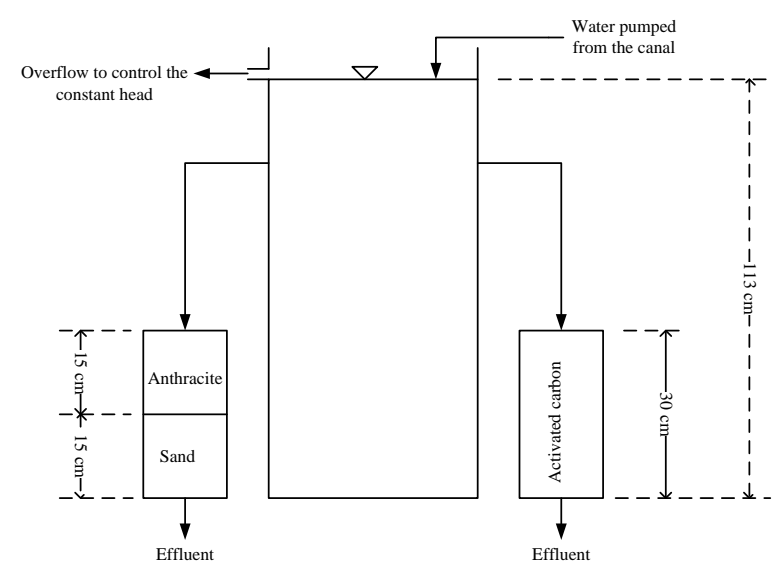

Fig. 1. Schematic diagram of the constant head permeable test.

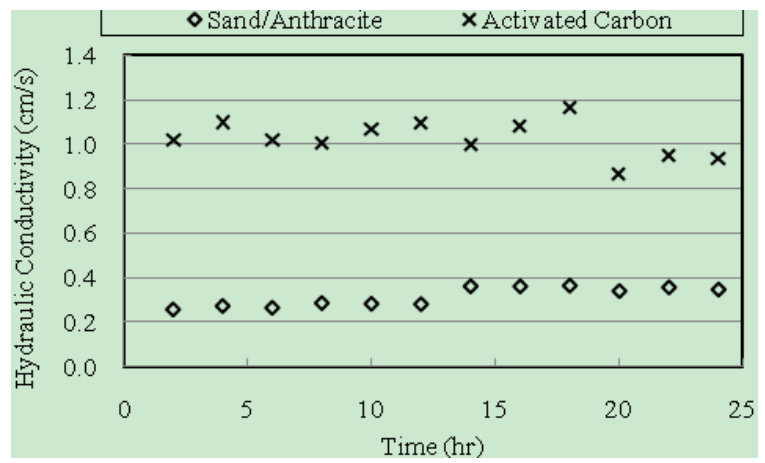

Fig. 2. Hydraulic conductivities of granular activated carbon and sand/anthracite

Once typical hydraulic conductivities of granular activated carbon and sand/anthracite were established, the effect of turbidity to the clogging of the subsurface drain can then be investigated. The test unit was set up next to a drainage canal on the campus in Thammasat University. Water pumped from a drainage canal which received the surface runoff from the road was fed into both pipes so the turbidity would be exactly the same in both cases. Effluents from both pipes were collected daily and the turbidity of both influents and effluents were measured as well. The experiment was carried out about 4 months which during the period there was on and off rainfall in the area. Finally, hydraulic conductivities of granular activated carbon and sand/anthracite were estimated.

\section{RESULTS AND DISCUSSIONS}

The base line hydraulic conductivities of granular activated carbon and sand/anthracite were shown in Fig. 2.

It is clearly shown from Fig. 2 that the hydraulic conductivity of granular activated carbon is greater than that of sand/anthracite due to the bigger grain size of granular activated carbon. After the hydraulic conductivities of both media reached the steady state, water from the drainage canal was pumped into the system. The hydraulic conductivity was calculated from (1);

$$
K=\frac{V L}{A h t}
$$

where $K$ is the hydraulic conductivity $(\mathrm{cm} / \mathrm{s}), V$ is the volume of effluent collected during a period of time $\left(\mathrm{cm}^{3}\right), L$ is the length of the porous media $(\mathrm{cm}), A$ is the cross sectional area of the PVC pipe $\left(\mathrm{cm}^{2}\right), H$ is the constant head $(\mathrm{cm})$ and $t$ is the duration to collect the effluent (s).

The hydraulic conductivities of granular activated carbon and sand/anthracite along with the turbidity of inflow and outflow are shown in Fig. 3 and 4, respectively.

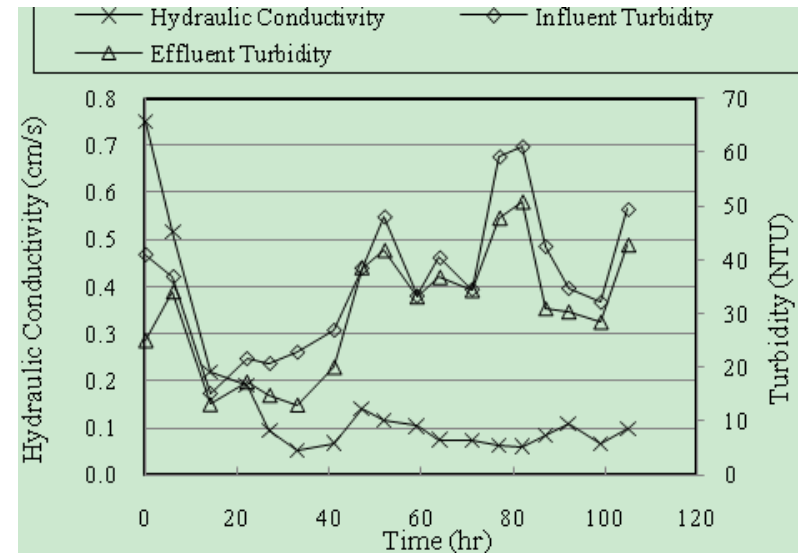

Fig. 3. The hydraulic conductivity of granular activated carbon compared with the influent and the effluent turbidity.

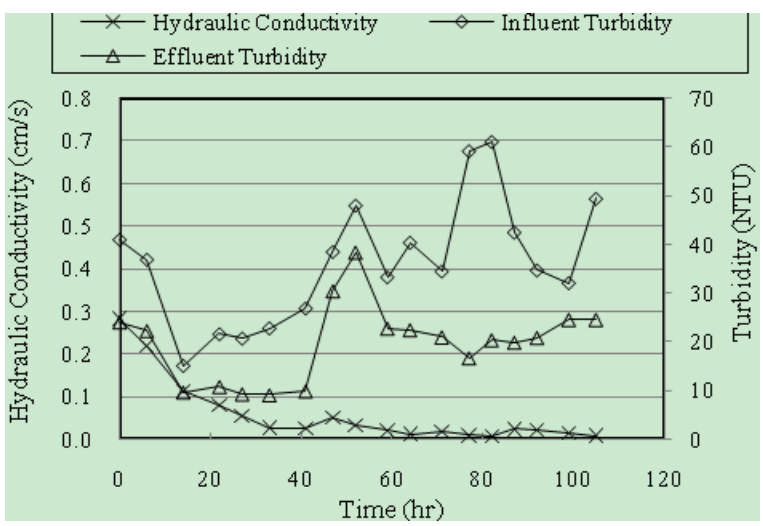

Fig. 4. The hydraulic conductivity of sand/anthracite compared with the influent and the effluent turbidity. 
Turbidities for both the influent and the effluent were measured when the water sample was collected using Hach 2100Q portable turbidimeter. Turbidity of the drainage canal was about 20 - 60 Nephelometer Turbidity Units (NTU) which was within the range of typical value of turbidity of river in Thailand. Water pumped from the drainage canal was distributed to both test units simultaneously therefore the influent turbidity was exactly the same. The fluctuation of the turbidity depended on the precipitation. Lack of rain resulted in higher turbidity of the canal. Sand/anthracite trapped more suspended solid particles than granular activated carbon did as it clearly showed in the effluent turbidity. The effluent turbidity for sand/anthracite column was less than that for activated carbon column. After passing through sand/anthracite column, water appeared to be clearer than outflow from granular activated column. Similar to the filtration system, anthracite with the smaller diameter was placed on top of sand, suspension solids would be trapped onto finer material. Fine particle can easily flow through granular activated carbon due to its bigger diameter.

Initially, hydraulic conductivities of granular activated carbon and sand/anthracite were rapidly reduced with time because the fine particle started to fill the void. About the $35^{\text {th }}$ hour, hydraulic conductivities of both columns approached the steady state. There were some spikes of hydraulic conductivity in the $47^{\text {th }}$ hour for both cases. Such a surge was a result of water being supplied sporadically to the system. The pump was only operated during the daytime and turned off during the night time. Moreover, the experiment was done within 4 months period so there was a month that the test was stopped entirely due to a long holiday. During that time, the column was left to dry and so was the fine particle in the media. Once the operation was started again, the water then pushed those dried particles out of the void resulting in the jump in hydraulic conductivity. However, as soon as the pump was run regularly the hydraulic conductivity dropped to the steady state again. The on-and-off operation of the pump was actually an imitation of the rainfall pattern.

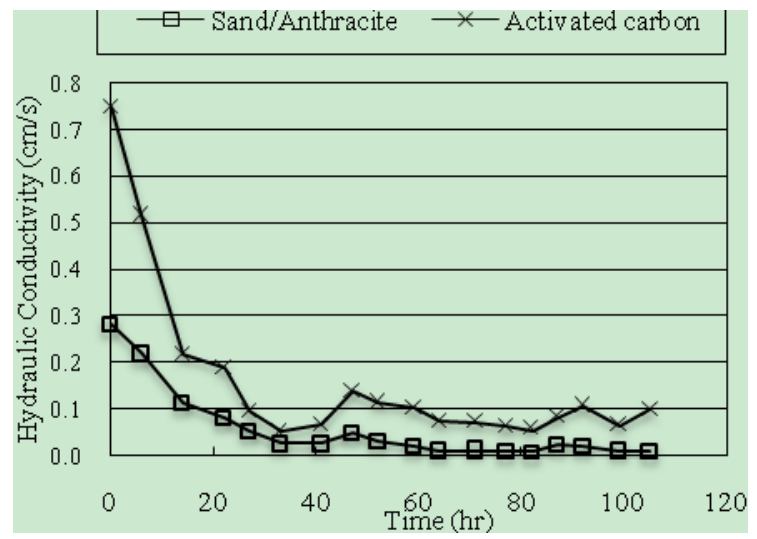

Fig. 5. The Hydraulic conductivity comparison between granular activated carbon and sand/anthracite.

Compared the hydraulic conductivity between two porous media was shown in Fig. 5. The hydraulic conductivity of granular activated carbon decreased more drastically than that of sand/anthracite. Eventually, the hydraulic conductivity have reached a steady state.

Average steady state hydraulic conductivities of granular activated carbon and sand/anthracite were about $0.085 \mathrm{~cm} / \mathrm{s}$ and $0.021 \mathrm{~cm} / \mathrm{s}$, respectively. Compared with the hydraulic conductivity of unconsolidated gravel of $0.01-100 \mathrm{~cm} / \mathrm{s}$ [14] hydraulic conductivities of both media in this experiment were still within the range of gravel. However, it is recommended that the hydraulic conductivity of the envelope should be bigger than that of the adjacent soil so water will be allowed to flow downward into the soil [15]. For this work, there is no specific area where this subsurface drain would be installed so hydraulic conductivities of the tested materials can only be compared with the one of gravel. To install this modified subsurface drain in the field, the hydraulic conductivity of the local soil is certainly needed to warrant the success of the system. As for the life span of activated carbon, a remediation site in Brunn am Gebirge, Austria using activated carbon as adsorbent in an adsorptive reactor and barrier has been operated since October 1999 [16]. In their report in 2005 , the system has been working well throughout those periods.

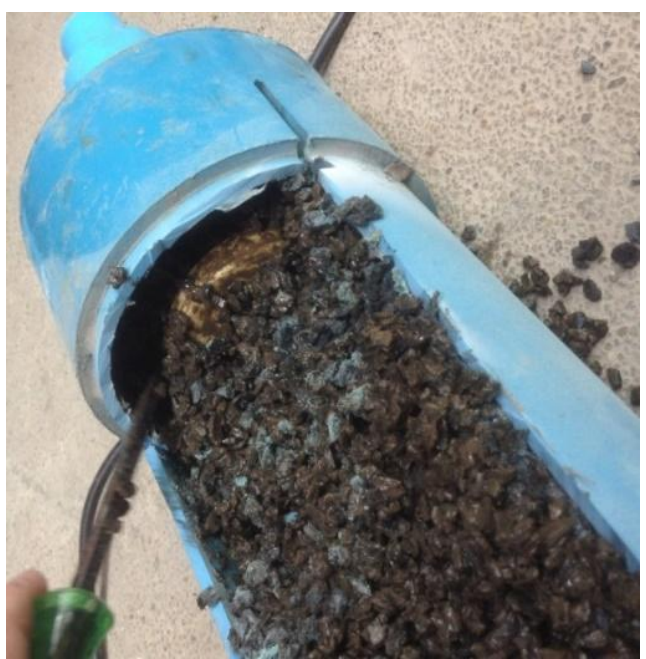

Fig. 6. Granular activated carbon.

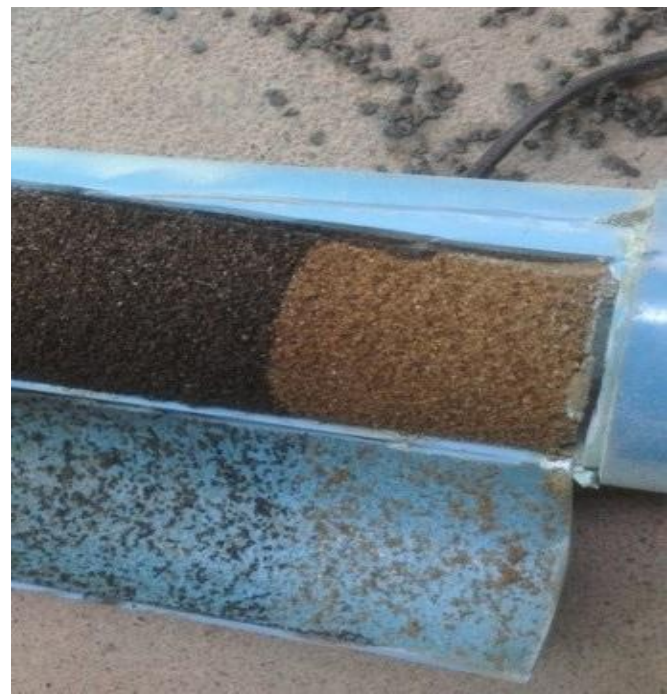

Fig. 7. A composite material: sand/anthracite.

After the test had ended, both test columns were cut off to check the condition of the porous media, Fig. 6 and Fig. 7 show the content in granular activated carbon and a composite material of sand and anthracite, respectively. For both cases, the porous media was covered with the sediment from the canal but it did not show any signs of total blockage 
of the media. Sand and anthracite were still separated as initially packed. There was little or almost no trace of sediment in sand part, the superior filtration ability of anthracite is an essential attribute for a rather clean sand after the experiment.

\section{CONCLUSIONS}

From this simple experiment, it can be concluded that gravel in the envelope of subsurface drain can be replaced with granular activated carbon or the composite material of sand and anthracite. Hydraulic conductivities of both porous media tested with water from the natural canal with typical turbidity were similar to that of gravel which is normally used as permeable material in envelope. However, granular activated carbon would be a better media than sand/anthracite because its steady state hydraulic conductivity was higher; hence its longevity would be greater. Activated carbon can remove any contaminant from the surface runoff and also can act as a permeable media in the subsurface drain. This modified subsurface drain is another sustainable practice to a routine drainage system and in the meantime; it can also give water back to the groundwater system.

\section{ACKNOWLEDGMENT}

This work was supported in part by the department of Civil Engineering, Thammasat University.

\section{REFERENCES}

[1] The World Bank, "Thai flood 2011, overview: Rapid assessment for resilient recovery and reconstruction planning," The World Bank, pp. 24, 2012.

[2] H. Fan, D. He, and H. Wang, "Environmental consequences of damming the mainstream Lancang-Mekong river: A review," Earth-Science Reviews, vol. 146, pp. 77-91, July. 2015.

[3] H. Bouwer and R. Rice, "Effect of water depth in groundwater recharge basins on infiltration," J. Irrig. Drainage Eng, vol. 115, pp. 556-567, Aug. 1989.

[4] Z. Sheng, "An aquifer storage and recovery system with reclaimed wastewater to preserve native groundwater resources in El Paso, Texas," J. Environ Management, vol. 75, pp. 367-377, June 2005.

[5] S. Kumar, T. Ramilan, C. A. Ramarao, C. S. Rao, and A. Whitbread, "Farm level rainwater harvesting across different agro climatic regions of India: Assessing performance and its determinants," Agricultural Water Management, vol. 176, pp. 55-66, Oct. 2016.

[6] K. E. Lee, M. Mokhtar, M. M. Hanafiah, A. A. Halim, and J. Badusah, "Rainwater harvesting as an alternative water resource in Malaysia: Potential, Policies and development," J. of Cleaner Production, vol. 126, pp. 218-222, July 2016.

[7] W. Lin, D. G. Park, S. W. Ryu, B. L. Lee, and Y. H. Cho, "Development of permeability test method for porous concrete block pavement materials considering clogging," Construction and Building Materials, vol. 118, pp. 20-26, Aug 2016.

[8] D. Thorpe and Y. Zhuge, "Advantages and disadvantages in using permeable concrete pavement as a pavement construction material," in
Proc $26^{\text {th }}$ Annual ARCOM Conference, Leeds, UK, Association of Researchers in Construction Management, pp. 1341-1350, Sept. 2010.

[9] S. Smittakorn, S. Dechakampoo, and S. Suetrongtrakool, "A new method to recharge groundwater using subsurface drain," Advanced Materials Research, vol. 931-932, pp. 813-817, 2014.

[10] T. Aljazzar and B. Kocher, "Monitoring of contaminant input into roadside soil from road runoff and airborne deposition," Transport Research Arena TRA 2016, pp. 2717-2723, 2016.

[11] F. J. Charters, T. A. Cochrane, and A. D. O'Sullivan, "Untreated runoff quality from roof and road surface in a low intensity rainfall climate," Science of the Total Environment, vol. 550, pp. 265-272, April 2016.

[12] Georgi, A. Schierz, K. Mackenzie, and F. D. Kopinke, "Colloidal activated carbon for in-situ groundwater remediation - Transport characteristics and adsorption of organic compounds in water-saturated sediment columns," J. of Contaminant Hydrology, vol. 179, pp. 76-88, Aug. 2015

[13] N. A. Oladoja, B. Helmreich, and H. A. Bello, "Towards the development of a reactive filter from green resource for groundwater defluoridation," Chemical Engineering Journal, vol. 301, pp. 166-177, Oct. 2016.

[14] D. I. Leap, "Geological occurance of grounwater," The Handbook of Groundwater Engineering, CRC Press LLC and Springer-Verlad, ch. 1, 1999

[15] L. C. P. M. Stuyt, W. Dierickx, and J. M. Beltran, "Materials for subsurface land drainage system. FAO irrigation and drainage paper 60 Rev. 1," Food and Agriculture Organization of the United Nations, Rome, 2005.

[16] P. Niederbacher and M. Nahold, "Installation and operation of an adsorptive reactor and barrier (AR\&B) system in Brunn am Gebirge, Austria," Long-Term Performance of Permeable Reactive Barriers, Elsevier, 2005

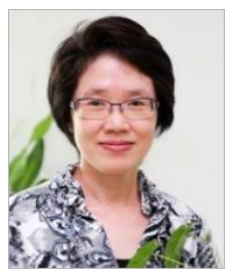

Sunisa Smittakorn was born in Bangkok, Thailand. She finished her undergraduate degree in water resources engineering from Kasetsart University, Thailand in 1989. She received her master degree in civil engineering from the New York University Tandon School of Engineering (formally known as Polytechnic University; Brooklyn campus), U.S.A. in 1993 and her PhD in civil engineering from Colorado State University, U.S.A. in 2001. She later took her postdoctoral fellowship in Colorado State University in 2008 under the scholarship from the American Association of University Women (AAUW).

After her graduation in 2001, she has taught in the department of civil engineering, Thammasat University. Her research interests are groundwater contamination and groundwater recharge.

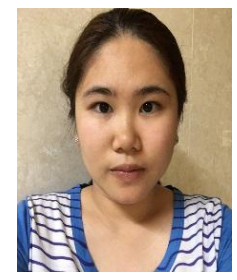

Sasiphorn Sasinawaworakul was born in Prachin Buri, Thailand. She is currently studying in civil engineering, Thammasat University, Thailand. Her internship was with Thai Takenaka International Ltd At present, along with her study, she has also helped her parent with their construction company based in her town, Chachoengsao. Most of their work are the bridge construction

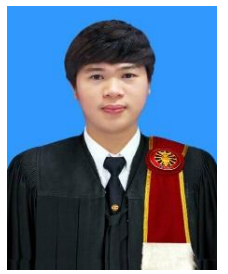

Phattara Chutsikarinton was born in KhonKaen, Thailand. He has just finished his bachelor degree in civil engineering from Thammasat University, Thailand in 2016. His intership was with Finesse Soil Testing, Co. Ltd. He has recently got a job as a site engineer in a construction firm in Thailand. 